\title{
TCF12 wt Allele
}

National Cancer Institute

\section{Source}

National Cancer Institute. TCF12 wt Allele. NCI Thesaurus. Code C97829.

Human TCF12 wild-type allele is located in the vicinity of $15 q 21$ and is approximately 371 $\mathrm{kb}$ in length. This allele, which encodes transcription factor 12 protein, plays a role in both tissue differentiation and transcriptional regulation. A chromosomal translocation $\mathrm{t}(9 ; 15)$ (q22;q21) of this gene and the NR4A3 gene is associated with extraskeletal myxoid chondrosarcoma. 